I Made Nada, dkk. : Model Penanggulangan Sedimentasi Danau Berbasis Masyarakat .....

\title{
MODEL PENANGGULANGAN SEDIMENTASI DANAU BERBASIS MASYARAKAT DI PULAU BALI
}

\author{
I Made Nada ${ }^{1}$, Ida Bagus Suryatmaja ${ }^{2}$, I Gusti Ngurah Alit Wiswasta ${ }^{3}$ \\ ${ }^{1}$ Jurusan Teknik Sipil, Universitas Mahasaraswati, Denpasar \\ ${ }^{2}$ Jurusan Teknik Sipil, Universitas Mahasaraswati, Denpasar \\ ${ }^{3}$ Jurusan Pertanian, Universitas Mahasaraswati, Denpasar \\ *Crresponding author : Email : nada_brm@yahoo.cm
}

\begin{abstract}
ABSTRAK
Penanggulangan sedimentasi danau berbasis masyarakat diarahkan untuk mempertahankan keseimbangan yang dinamisDanau Batur, Danau Beratan, Danau Buyan dan Danau Tamblingan. Proses sedimentasi danau ini dipicu oleh pola pengelolaan lahanlahan pertanian di pinggir danau kurang memperhatikan aspek-aspek konservasi tanah dan air. Tujuan penelitian ini adalah ; (1) untuk memperoleh model penanggulangan sedimentasi yang berbasis masyarakat, (2) Pemetaan Pengelolaan lahan di pinggir danau, (3) Stategi pengendalian erosi di tepian danau.Penelitian ini adalah penelitian field experiment dan surpei, pengambilan sampel dilakukan secara purposive sampling di Danau Batur 20 sampel, Danau Beratan 16 sampel, Danau Buyan 16 sampel dan Danau Tamblingan 12 Sampel. Data dukungan sosial ekonomi masyarakat ditentukan sebanyak 180 responden secara cluster sampling. Wawancara dan kuesioner berupa pertanyaan tertutup dalam skala konvensional. Karakteristik danau dianalisis statistik deskriptif menggunakan alat analisis SPSS. Pemetaan lahan dilakukan dengan metode GPS dengan perangkat GIS. Memprediksi erosi menggunakan Model The Universal Soil Loss Equation (USLE) sedangkan untuk sedimentasi menggunakan model Sediment Stanford.Analisis data untuk mengetahui model perkembangan laju sedimentasi di danau akibat erosi yang terjadi, dilakukan dengan cara analisis regreresi non linear. Hasil analisis tersebut diuji dua sisi dengan tingkat kepercayaan 95\% tersebut terhadap data sedimen yang dimodelkan apakah berpengaruh sangat signifikan atau tidak.
\end{abstract}

Kata Kunci : Danau, Erosi, Sedimentasi

\begin{abstract}
Countermeasures of community-based lake sediments are directed at maintaining the dynamic balance of Lake Batur, Beratan Lake, Lake Buyan and Lake Tamblingan. Sedimentation process of this lake is triggered by the pattern of management of agricultural land on the edge of the lake is less attention to aspects of soil and water conservation. The purpose of this research is; (1) to obtain a community-based sedimentation prevention model, (2) Mapping Land management on the edge of the lake, (3) erosion control strategy at the edge of the lake. This research is field experiment and surpei research, sampling is done by purposive sampling at Batur Lake 20 samples, Beratan Lake 16 samples, Lake Buyan 16 samples and Danau Tamblingan 12 Sampel. The socio-economic support data of the community was determined by 180 respondents in cluster sampling. Interviews and questionnaires are closed questions on a conventional scale. Characteristics of the lake were analyzed descriptive statistics using
\end{abstract}


SPSS analysis tool. Land mapping is done by GPS method with GIS device. Predict erosion using the Universal Soil Loss Equation (USLE) Model while for sedimentation using the Stanford Sediment model. Data analysis to find out the model of development of sedimentation rate in lake due to erosion that happened, done by non linear regreresi analysis. The results of the analysis are tested on both sides with $95 \%$ confidence level on sediment data that is modeled whether or not significant effect

Keywords :Lake, Erosion, Sedimentation

\section{PENDAHULUAN}

Danau yang ada di Pulau Bali kondisi permukaaan airnya terus mengalami penurunan. Proses sedimentasi dan pendangkalan danau ini dipicu oleh pola pengelolaan lahan-lahan pertanian di pinggir danau kurang memperhatikan aspek-aspek konservasi tanah dan air.Kerusakan lahan banyak terjadi pada lahan kering terutama pada lahan yang ditanami tanaman pangan dan perkebunan rakyat. Kerusakan terjadi antara lain karena lahan kering terbuka oleh pengolahan tanah, pembakaran, penyiangan dan penggembalaan sehingga tanah mudah tererosi dan longsor.Erosi dan banjir dapat menurunkan kualitas dan kuantitas SDA dan air sehingga produktivitas sumber daya tersebut menjadi semakin menurun. Tujuan penelitian ini adalah ; (1) untuk memperoleh bentuk model penanggulangan sedimentasi yang berbasis masyarakat, (2) Pemetaan Pengelolaan lahan-lahan pertanian dan aktivitas wisata di pinggir danau, (3) Stategi pengendalian erosi di tepian danau. Target yang ingin dicapai berupa bentuk model Penanggulangan sedimentasi danau dan bentuk model pemetaan prediksi erosi dikawasan masingmasing danau. Penelitian ini dilasanakan di empat danau yaitu : Danau Batur di Kabupaten Bangli, Danau Beratan di Kabupaten Tabanan, Danau Buyan di Kabupaten buleleng dan Danau Tamblingan di Kabupaten Buleleng.

\section{METODE PENELITIAN}

\subsection{Bagan Alir Penelitian}

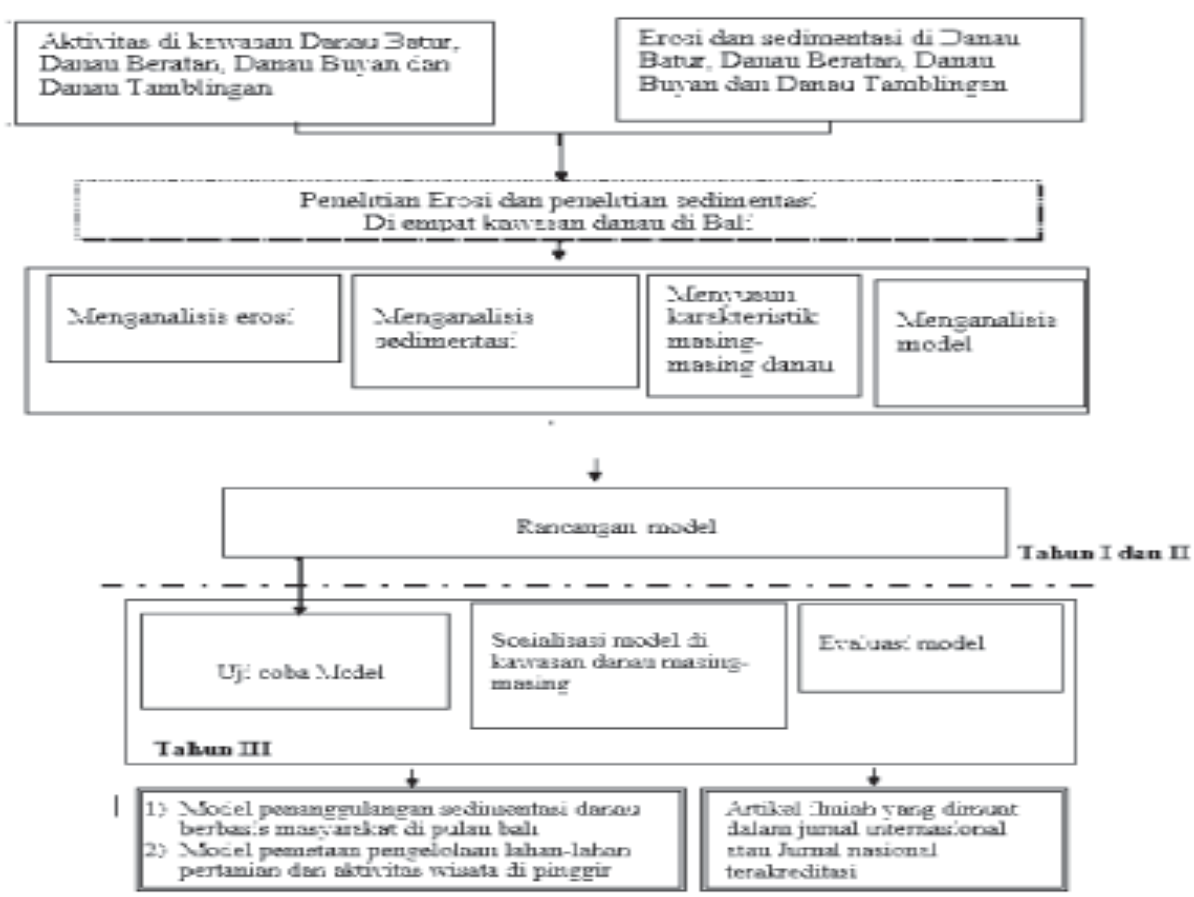

Gambar 1.Bagan Alir Penelitian 


\subsection{Desain Peneltian}

Penelitian yang akan dilaksanakan adalah penelitian lapangan (field experiment), survey lapangan mengenai kondisi lahan dari kawasan danau, penelitian terhadap kondisi biofisik dari lokasi penelitian berupa jenis, struktur dan tekstur tanah; morpologi atau topografi berupa panjang dan kemiringan lereng; sifat geologi/geofisik lahan; vegetasi; iklim berupa curah hujan dan intensitas hujan; pemetaan lahan bervegetasi dan tanpa vegetasi; dan pemetaan lahan tererosi dan hal ini dilakukan dengan GPS (Geographic Positioning System) dengan perangkat GIS (Geographic Information System); dan survey mengenai partisipasi masyarakat dalam penanggulangan sedimentasi yang terjadi di danau dan pengendalian erosi.

\subsection{Lokasi Penelitian dan Sumber Data}

Penelitian dilakukan di empat danau yaitu : Danau Batur di Kabupaten Bangli, Danau Beratan di Kabupaten Tabanan, Danau Buyan di Kabupaten buleleng dan Danau Tamblingan di Kabupaten Buleleng. Penelitian ini adalah penelitian field experiment dan surei, pengembilan sampel dilakukan secara purposive sampling di Danau Batur 20 sampel, Danau Beratan 16 sampel, Danau Buyan 16 sampel dan Danau Tamblingan 12 Sampel. Data dukungan sosial ekonomi masyarakat ditentukan sebanyak 180 responden secara cluster sampling di empat danau yang ada di Bali. Wawancara dan kuesioner berupa pertanyaan tertutup dalam skala konvensional (1 sampai dengan 10).

\subsection{Kegiatan Pada Tahun Pertama dan Kedua}

\subsubsection{Pemetaan Kondisi Lahan dan Pendugaan Erosi di Kawasan Danau}

Penelitian pada tahun pertama diawali dengan pembuatan peta unit lahan yang berdasarkan peta geomorfologi, peta kemiringan lereng dan peta penutupan lahan. Pengertian unit lahan menurut Direktorat Jenderal Reboisasi dan Rehabilitasi Lahan (1998) adalah merupakan gambaran unsur-unsur lahan yang kurang lebih sama, yaitu kesamaan dalam topografi, batuan/struktur, proses pembentukan, kemiringan lereng dan vegetasinya. Untuk dapat menggambarkan unsur-unsur unit lahan kedalam satu kesatuan pemetaan dengan cara tumpang tindih. Dengan catatan bahwa skala peta yang ditumpang tindihkan sama atau seragam.

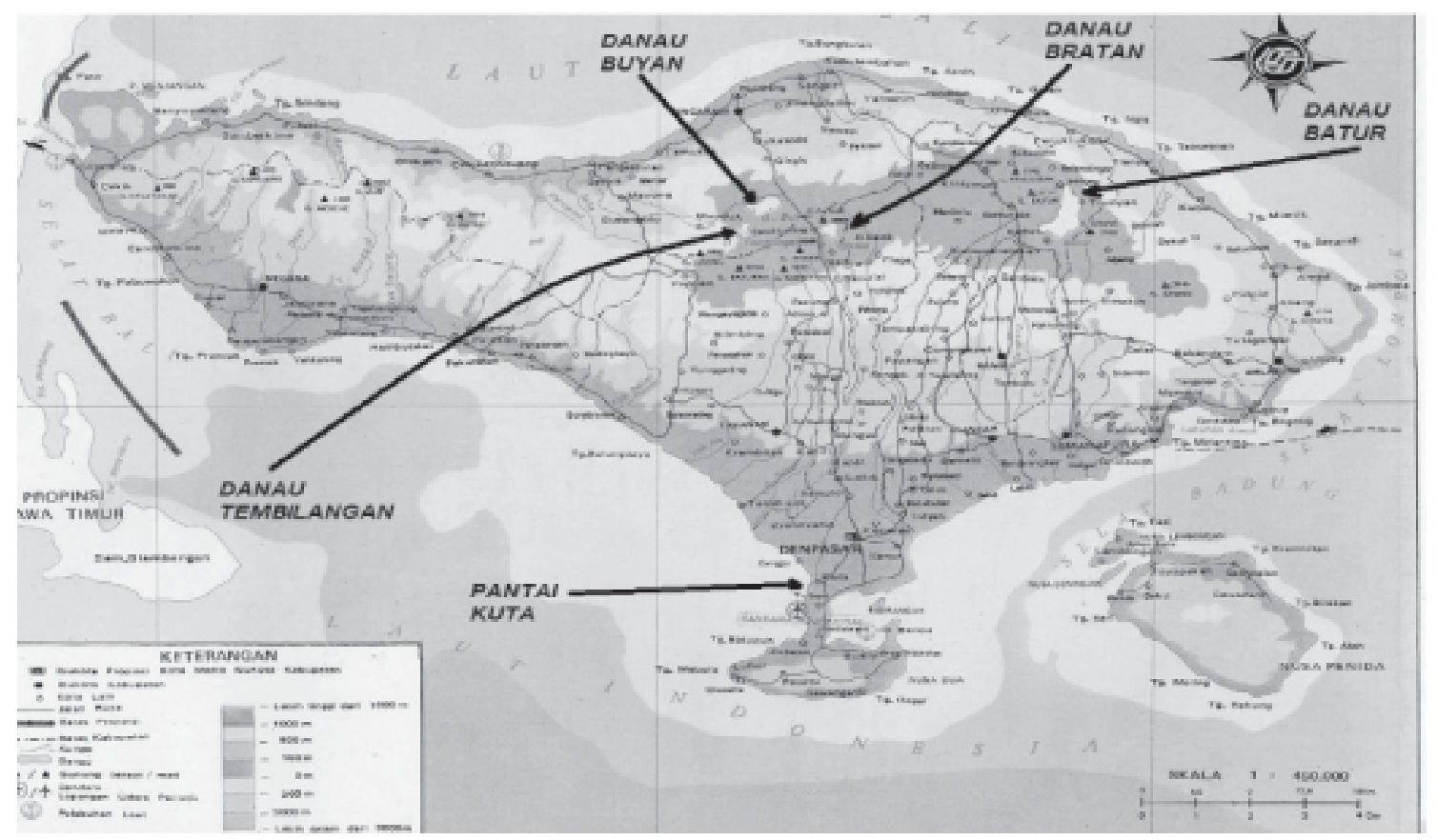

Gambar 2. Peta Lokasi Danau di Pulau Bali (sumber : www.google.com) 
Langkah-langkah pemetaan unit lahan adalah sebagai berikut :

a) Letakkan peta geomorfologi yang tersedia dari hasilCitra satelit,

b) Tumpang tindihkan dengan peta kemiringan lereng. Daerah yang dibatasi oleh batas bentuk lahan dan batas kemiringan lereng adalah merupakan sub unit bentuk lahan,

c) Hasil dari dua tersebut diatas ditumpang tindihkan lagi dengan peta penutupan lahan (land cover) atau hasil dari Citra satelit, dengan demikian diperoleh unit lahan yang merupakan satu pemetaan.

Setiap unit lahan yang diberikan simbul sesuai ketentuan yang ada, baik bentuk lahan/geomorfologi, kelas kemiringan lereng maupun penutupan lahan. Sebagai contoh unit lahan F1ITS, dibaca:

F1 : dataran fluvial

I : kemiringan lereng (8-15\%)

TS : tanaman semusim

Dari hasil penentuan unit lahan dapat dibedakan :

F1 ITS $=$ Dataran fluvial kemiringan $8-15 \%$ tanaman semusim

F1 KC = Dataran fluvial kemiringan $8-15 \%$ kebun campuran

S1 III TS = Lereng kaki kemiringan 15-25\% tanaman semusim
$\mathrm{F} 1 \mathrm{III} \mathrm{KC}=$ Dataran fluvial kemiringan $15-25 \%$ kebun campuran

F1 III Vt1 = Dataran fluvial kemiringan 15-25\% vegetasi lebat

F1 III Vt2 = Dataran Flufial kemiringan 15-25\% vegetasi sedang

D1 III Vt2 = Perbukitan terkikis kemiringan 15-25 vegetasi sedang

$\mathrm{D} 1 \mathrm{IVKC}=$ Perbukitan terkikis kemiringan $25-40 \%$ kebun campuran

S1 IVVt1 = Lereng kaki kemiringan 25-40\% vegetasi lebat

D1 IV Vt2 = Perbukitan terkikis kemiringan 25-40\% vegetasi sedang

D2 VTS = Pegunungan terkikis kemiringan $>$ $40 \%$ tanaman semusim

Dasar pendugaan atau prediksi dilakukan dengan menggunakan metode pendugaan erosi oleh Wiscmeier dan Smith (1978)yang dikenal dengan nama Universal Soil Loses Equation (USLE) atau Persamaan Umum Kehilangan Tanah (PUKT), seperti pada persamaan (6). Hasil kuantitatif (nilai) prediksi erosi tersebut kemudian dibandingkan dengan nilai batas erosi toleransi (Edp) untuk menentukan perlu atau tidak suatu lahan dikorsevasi. Untuk tanahtanah di Indonesia lebih lanjut dapat dijelaskan seperti pada tabel 2.1 .

Selanjutnya ditentukan klas tingkat bahaya erosi dengan berpedoman pada penjelasan tabel 2.2.

Tabel 2.1. Pedoman Penetapan nilai Edp untuk tanah di Indonesia

\begin{tabular}{|c|c|c|}
\hline No. & Sifat tanah dan sub Stratum & $\begin{array}{c}\text { Nilai A } \\
(\mathrm{mm} / \mathrm{th})\end{array}$ \\
\hline 1. & Tanah sangat dangkal di atas batuan induk & 0,00 \\
\hline 2. & $\begin{array}{l}\text { Tanah sangat dangkal di atas bahan induk yang telah melapuk ( bahan } \\
\text { tak terkonsolidasi) }\end{array}$ & 0,40 \\
\hline 3. & Tanah dangkal diatas batuan induk yang telah lapuk & 0,80 \\
\hline 4. & $\begin{array}{l}\text { Tanah dengan kedalaman sedang diatas batuan induk yang telah melapuk } \\
\text { Tanah dengan lapisan bawah kedap air, diatas substrata yang telah }\end{array}$ & 1,20 \\
\hline 5. & $\begin{array}{l}\text { melapuk } \\
\text { Tanah dalam dengan lapisan bawah berpermeabilitasrendah, diatas }\end{array}$ & 1,60 \\
\hline 6. & $\begin{array}{l}\text { substrata yang telah melapuk. } \\
\text { Tanah dalam dengan lapisan bawah berpermeabilitas tingoi, di atas }\end{array}$ & 2,00 \\
\hline 7. & substrata yang telah melapuk & 2,50 \\
\hline
\end{tabular}

Sumber : Arsyad, 1989 
I Made Nada, dkk. : Model Penanggulangan Sedimentasi Danau Berbasis Masyarakat .....

Tabel 2.2. Klasifikasi Tingkat Bahaya Erosi ( TBE)

\begin{tabular}{|c|c|c|c|c|c|c|}
\hline \multirow{4}{*}{$\begin{array}{l}\text { Solum tanah ( } \\
\qquad \mathrm{Cm})\end{array}$} & \multicolumn{5}{|c|}{ Kelas Erosi } & \multirow{3}{*}{ Keterangan } \\
\hline & I & II & III & IV & $\bar{V}$ & \\
\hline & \multicolumn{5}{|c|}{ Erosi ( ton/ha/th ) } & \\
\hline & $<15$ & $15-60$ & $60-180$ & $180-480$ & $>480$ & \multirow{5}{*}{$\begin{array}{l}0-\mathrm{SR}=\begin{array}{l}\text { Sangat } \\
\quad \text { Ringan }\end{array} \\
\mathrm{I}-\mathrm{R}=\text { Ringan } \\
\mathrm{II}-\mathrm{S}=\text { Sedang } \\
\mathrm{III}-\mathrm{B}=\text { Berat } \\
\mathrm{IV}-\mathrm{SB}=\text { Sangat } \\
\text { Berat }\end{array}$} \\
\hline $\begin{array}{c}\text { Dalam } \\
>90\end{array}$ & $\begin{array}{c}\mathrm{SR} \\
0\end{array}$ & $\begin{array}{l}\mathrm{R} \\
\mathrm{I}\end{array}$ & $\begin{array}{l}\text { S } \\
\text { II }\end{array}$ & $\begin{array}{c}\text { B } \\
\text { III }\end{array}$ & $\begin{array}{l}\text { SB } \\
\text { IV }\end{array}$ & \\
\hline $\begin{array}{l}\text { Sedang } \\
60-90\end{array}$ & $\begin{array}{l}\mathrm{R} \\
\mathrm{I}\end{array}$ & $\begin{array}{l}\text { S } \\
\text { II }\end{array}$ & $\begin{array}{c}\mathrm{B} \\
\text { III }\end{array}$ & $\begin{array}{l}\text { SB } \\
\text { IV }\end{array}$ & $\begin{array}{l}\text { SB } \\
\text { IV }\end{array}$ & \\
\hline $\begin{array}{c}\text { Dangkal } \\
30-60\end{array}$ & $\begin{array}{l}\mathrm{S} \\
\mathrm{II} \\
\end{array}$ & $\begin{array}{l}\text { B } \\
\text { III }\end{array}$ & $\begin{array}{l}\mathrm{SB} \\
\text { IV }\end{array}$ & $\begin{array}{l}\text { SB } \\
\text { IV }\end{array}$ & $\begin{array}{l}\text { SB } \\
\text { IV }\end{array}$ & \\
\hline $\begin{array}{c}\text { Sangat Dangkal } \\
<30\end{array}$ & $\begin{array}{c}\mathrm{B} \\
\mathrm{III}\end{array}$ & $\begin{array}{l}\text { SB } \\
\text { IV }\end{array}$ & $\begin{array}{l}\text { SB } \\
\text { IV }\end{array}$ & $\begin{array}{l}\text { SB } \\
\text { IV }\end{array}$ & $\begin{array}{l}\text { SB } \\
\text { IV }\end{array}$ & \\
\hline
\end{tabular}

Sumber : Direktorat Jenderal Reboisasi dan Rehabilitasi Lahan, 1998

\subsubsection{Bahan dan Instrumen yang Diperlukan}

Bahan dan Instrumen yang digunakan dalam penelitian ini adalah :

Peta Situasi Provinsi Bali skala $1: 750.000$, a) Peta Penutupan Lahan di kawasan danau, b) Peta Geomorfologi kawasan danau skala $1: 25.000$, e) Peta Unit Lahan kawasan danau skala $1: 25.000$, f) Peta Kawasan Hutan Pulau Bali skala 1 : 25.000, g) Peta Tanah Kabupaten Bangli, Kabupaten Tabanan, Kabupaten Buleleng skala $1: 25.000$, h) Peta Tata Guna Lahan Kabupaten Bangli, Kabupaten Tabanan, Kabupaten buleleng skala $1: 25.000$, dan perangkat GIS (Geographic Information System)

\subsection{Penelitian pada Tahun Kedua}

Melakukan pengeboran di masing-masing danau untuk mendapatkan ketebalan dan jenis tanah sedimentasi. Pengeboran dilakukan sepanjang garis pantai danau yang senlanjutnya dianalisis daya tampung dan tutupan mata air danau.

\subsection{Penelitian pada tahun ke tiga}

\subsubsection{Model Usaha Konservasi Tanah dan Rehabilitasi Lahan}

Usaha-usaha konservasi tanah dan rehabilitasi lahan yang yang harus dilaksanakan berdasarkan indeks pengelolaan tanaman (C) dan pengelolaan tanah (P) dengan mempertimbangkan kondisi fisik (topografi, kedalaman tanah dan erodibilitas tanah).

Untuk menentukan usaha konservasi tanah dan rehabilitasi lahan maka dipilih indeks faktor pengelolaan tanaman $(\mathrm{C})$, dan pengelolaan tanah $(\mathrm{P})$ seperti disajikan pada Tabel 4,5,6 dan 7.Data yang dikumpulkanmeliputi data primer dan data sekunder.

\subsubsection{Pemilihan vegetasi untuk konservasi}

Setelah melalui berbagai analisa yang dibutuhkan dalam penentuan variable yang berkait dengan perancangan model konservasi tanah maka pemilihan vegetasi didasarkan atas hasil analisis tersebut. Tanaman utama yang sudah terbukti sangat baik dalam daya pegang air tanah. Disamping penanaman berbagai vegetasi di sepanjang kawasan danau dan pada kebun masyarakat pendamping yang lokasinya dipilih berdasarkan titik-titik konservasi dimana ditentukan minimal 5 titik (lahan) yang akan dipilih dalam penanaman tanaman konservasi.

\subsubsection{Pengukuran keberhasilan pelaksanaan konservasi dan rehabiliasi lahan}

Pelaksanaan penanaman tanaman konservasi membutuhkan peran serta masyarakat sekitar kawasan danau agar secara bersama-sama melaksakanan penanaman dan perawatan tanaman konservasi. Untuk itu sebelum kegiatan mulai diulaksanakan pada tahun II diawali dengan sosialisasi, pretest untuk mengetahui pemahaman masyarakat akan pentingnya konservasi tanah dan rehabilitasi lahan. Disamping itu untuk mengukur tingkat keberhasilan pelaksanaan kegiatan konservasi tanah dan rehabilitasi lahan maka diadakan evaluasi dengan memberikan post test pada masyarakat yang berpartsisipasi di sepanjang kawasan danau. Detail Pre dan Post test akan dilengkapi pada proposal tahun II 


\subsection{Bahan dan Instrumen Penelitian}

Bahan dan Instrumen yang digunakan dalam penelitian ini adalah :

a) Catatan curah hujan bulanan yang tercatat pada stasiun pengamat hujan di kecamatan Kintamani, Kecamatan Baturiti, Kecamatan Sukasada

b) Cangkul untuk mengambil sampel tanah, c) Bor tanah untuk mengukur kedalaman tanah atau solum tanah,

d) Meteran untuk mengukur panjang lereng,

e) Kinometer untuk menentukan kemiringan lereng $(\%)$

f) Kompas geologi untuk menentukan arah lempengan batuan,

g) Kompas untuk menentukan azimut titik sampel,

h) Pisau lapangan,

i) Kantong plastik dan ring sampel untuk menyimpan sampel tanah yang akan digunakan untuk analisis tekstur, permeabilitas dan kandungan bahan organik,

j) Stresoskop saku untuk pengamatan penutupan lahan, k) Daftar isian dan alat-alat tulis untuk mencatat data lapangan,

1) Perangkat Laboratorium Analisis Tanah (misal oven, tabung sedimentasi)

\subsection{Jenis dan Bentuk Data}

Dalam Penelitian ini dilakukan perhitungan prediksi erosi dengan metode pengumpulan data dengan metode deskriftif yaitu dengan mengumpulkan data primer dan skunder.

\section{A. Data Primer}

Data yang dikumpulkan terdiri dari : a) sifatsifat fisik tanah terdiri dari berat volume tanah, tekstur, kandungan bahan organik, struktur dan permeabilitas tanah (untuk menentukan nilai erodibilitas tanah).Penetuan berat volume tanah, tekstur dan kandungan bahan organik tanah dilakukan dengan analisis di laboratorium tanah pada Fakultas Pertanian Unud, untuk pengukuran sifat-sifat tanah dianalisis tekstur tanah dengan pipet, Bulk density dengan ring sampel, Permiabelitas dengan permeameter, bahan organik dengan walkley dan black, b) Pengabilan sampel tanah dilakukan dengan survey lapangan di empat kawasan danau baik di tepian maupun didalam danau. Kedalaman tanah diukur dengan menggunakan bor tanah, usaha konservasi tanah yang diterapkan baik secara sipil teknis atau vegetatif yang bertujuan untuk mengurangi erosi tanah, untuk menentukan niali faktor konservasi $\operatorname{tanah}(\mathrm{P})$.

\section{B. Data Sekunder}

Data sekunder yaitu data-data yang diperoleh dari informasi penggunaan lahan terkait meliputi : a) Data curah hujan untuk menghitung nilai erosivitas hujan. Data ini meliputi curah hujan rata-rata, jumlah hari hujan bulanan rata-rata dari curah hujan max 24 jam, b) Peta administrasi, Peta topografi, Peta jenis tanah, Peta penggunaan lahan dan peta penutupan vegetasi.

\subsection{Sumber Data}

Sumber data dalam penelitian ini antara lain : a) Dinas Kehutanan Provinsi Bali diambil data tentang peta administrasi daerah penelitian, b) Dinas Tata Ruang Kabupaten, c) Stasiun curah hujan.

\subsection{Analisis Data}

\section{A. Menentukan rata-rata erosi tahunan (A)}

Analisis data untuk menduga nilai faktor penentu erosi sesuai dengan persamaan USLE dilakukan dengan menggunakan faktor erosivitas hujan (R), faktor erodibilitas tanah (K), faktor panjang kemiringan lereng (LS) dan, faktor pengelolaan tanaman $(\mathrm{C})$ dan usaha konservasi tanah $(\mathrm{P})$ yang secara matematis dirumuskan sebagai berikut : $\mathbf{A}=\mathbf{R}$ x K x LS x C x P

\section{B. Menentukan Tingkat Bahaya Erosi (TBE)}

Tingkat bahaya erosi ditentukan dengan membandingkan antara nilai jumlah erosi tanah (A) dalam ton/ha/tahun dengan erosi yamg ditoleransikan Edp yang dikonversi dengan jumlah tanah yang tererosi dan dijabarkan dalam ton/ha/ tahun menjadi mm/tahun seperti persamaan berikut : Tebal tanah $(\mathrm{mm} /$ tahun $)=$ Ton/ha/tahun

$$
\mathrm{BV}\left(\mathrm{gr} / \mathrm{cm}^{3}\right) \times 10
$$

Dimana $: \mathrm{BV}=$ Berat volume tanah

Tingkat bahaya erosi ditentukan dengan membandingkan antara hasil analisis nilai erosi tahunan dalam ton/ha/tahun (A) dan kedalaman tanah (cm) dengan tingkat bahaya erosi. 
I Made Nada, dkk. : Model Penanggulangan Sedimentasi Danau Berbasis Masyarakat .....

Tabel 2.3. Penilaian Permeabilitas yang berlaku di Indonesia

\begin{tabular}{|l|l|c|c|}
\hline No & \multicolumn{1}{|c|}{ Kelas Permeabilitas } & cm/jam & Kode Penilaian \\
\hline 1. & Cepat ( Rapid ) & $>25,40$ & 1 \\
2. & Sedang sampai Cepat ( Moderate to rapid) & $12,70-25,40$ & 2 \\
3. & Sedang (Moderate ) & $6,30-12,70$ & 3 \\
4. & Sedang sampai lambat ( Moderate to Slow ) & $2,00-6,30$ & 4 \\
5. & Lambat ( Slow ) & $0,50-2,00$ & 5 \\
6. & Sangat lambat ( Very Slow ) & $<0,500$ & 6 \\
\hline
\end{tabular}

Sumber :Direktorat Jenderal Reboisasi dan Rehabilitasi Lahan, 1998

Tabel 2.4 Penilaian Struktur Tanah yang berlaku di Indonesia

\begin{tabular}{|l|l|c|c|}
\hline No. & \multicolumn{1}{|c|}{ Tipe Struktur Tanah } & Ukuran & $\begin{array}{c}\text { Kode } \\
\text { Penilaian }\end{array}$ \\
\hline 1. & Granuler Sangat halus & $<1 \mathrm{~mm}$ & 1 \\
2. & Granuler halus & $1-2 \mathrm{~mm}$ & 2 \\
3. & Granuler Sedang dan Besar & $2-10 \mathrm{~mm}$ & 3 \\
4. & Gumpal, Lempeng, atau Pejal & $>10 \mathrm{~mm}$ & 4 \\
\hline
\end{tabular}

Sumber :Direktorat Jenderal Reboisasi dan Rehabilitasi Lahan, 1998

\section{Menentukan Usaha Konversi Tanah dan Rehabilitasi Lahan}

Usaha konversi tanah dan rehabilitasi lahan dapat dievaluasi dengan mengetahui $\mathrm{C}$ dan $\mathrm{P}$ yang lebih kecil atau sama dan perbandingan antara nilai batas erosi toleransi dengan erosi potensial (RKLS) dengan persamaan :

\section{A \\ CP $\leq \frac{}{\text { RKLS }}$}

Dari hasil perhitungan indeks pengelolaan tanaman (C) dan pengelolaan tanah (P) sesuai persamaan di atas maka usaha konversi tanah dapat ditentukan dengan berpedoman pada Nilai Faktor C (Pengelolaan Tanaman) Pertanaman Tunggal, Nilai Faktor $\mathrm{C}$ dengan berbagai pengelolaan tanaman di Indonesia, Nilai Faktor P (Konservasi Tanah), Nilai Faktor CP (Pengelolaan Tanah dan Tanaman) dan Faktor P untuk beberapa bentuk usaha Pengawetan tanah. Penetapan usaha konversi tanah pada kawasan masing-masing danau, di samping menggunakan indeks pengelolaan tanaman $\mathrm{C}$ dan pengelolaan $\mathrm{P}$ sebagai pedoman, juga mempertimbangkan kondisi fisik lapangan.

\subsection{Luaran Penelitian}

Pemetaan kondisi lahan pada kawasan semua danau di Bali dengan prediksi atau pendugaan kejadian erosi

1) Model penanggulangan sedimentasi danau berbasis masyarakat di Bali

2) Peta Model usaha rehabilitasi lahan dan konservasi tanah pada kawasan Danau Batur, Danau Beratan, Danau Buyan dan Danau Tamblingan

3) Sebagai bahan ajar yang terkait dengan pemeliharaan dan pengelolaan lingkungan khususnya penanggulangan sedimentasi danau dan pengendalian erosi 


\subsection{Indikator Capaian}

Terciptanya pemetaan dalam satu peta yang menyangkut berbagai hal yang berhubungan dengan penelitian ini yaitu : wilayah kawasan danau, elevasi/ kemiringan, topografi, vegetasi, prediksi erosi

1) Terciptanya model penanggulangan sedimentasi danau berbasis masyarakat yang bisa dilaksanakan secara mudah oleh seluruh masyarakat di kawasan masing-masing danau.

2) Terciptanya model usaha rehabilitasi lahan dan konsevasi tanah yang praktis dan efisien dapat diterima oleh masyarakat untuk mencegah dan mengendali-kan erosi
3) Terciptanya sebuah buku ajar yang terkait dengan penanggulangan sedimentasi, konservasi tanah, rehabilitasi lahan dengan berbagai vegetasi pilihan untuk konservasi

\section{HASILDANPEMBAHASAN}

\subsection{Ijin Penelitian}

Ijin penelitian dikeluarkan oleh Pemerintah Provinsi Bali Dinas Penanaman Modal Dan Pelayanan Terpadu Satu Pintu gambar 4.1 yang selanjutnya diserahkan ke desa di kawasan danau.

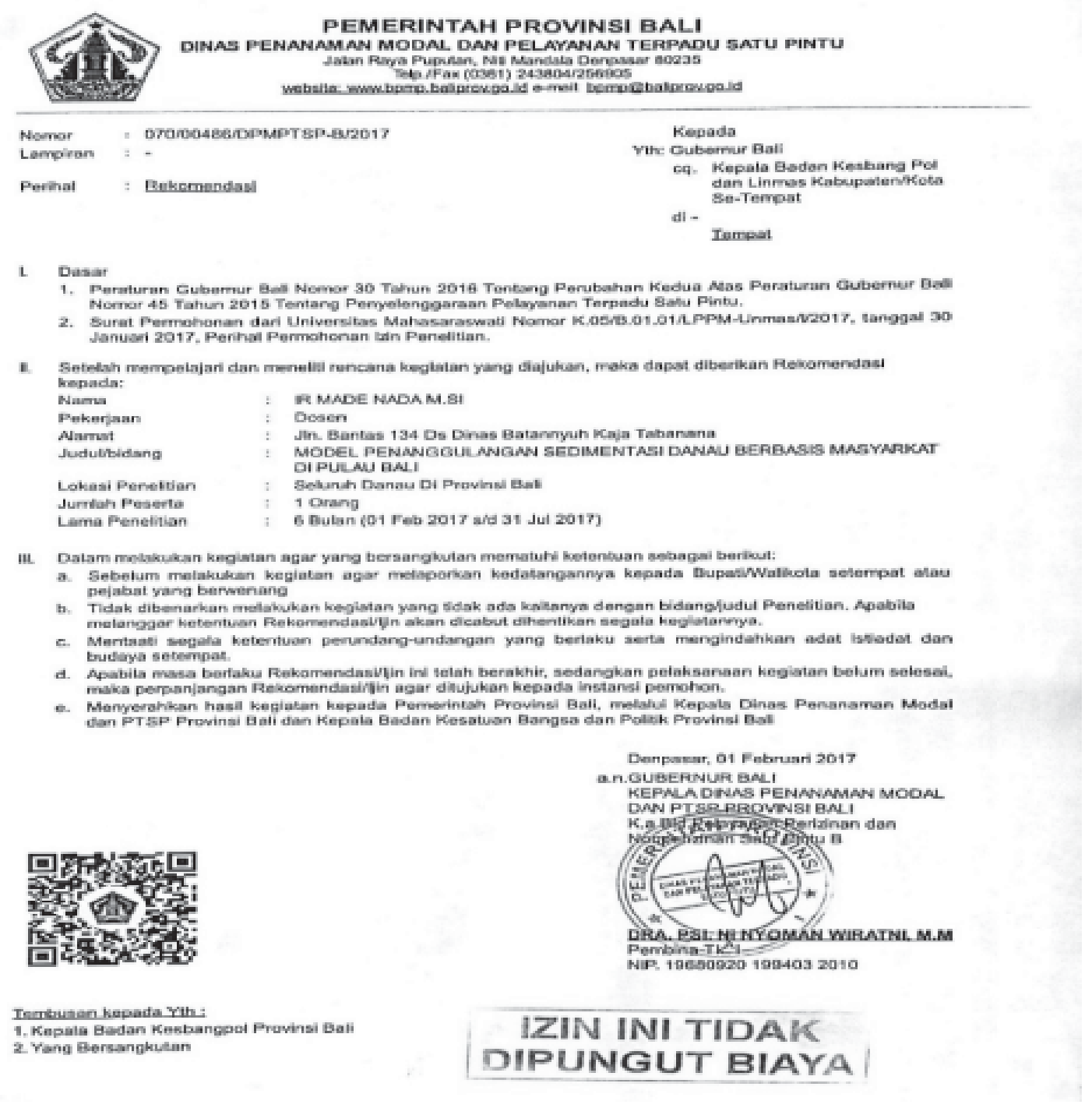

Gambar 3 Ijin Penelitian Seluruh Danau di Provinsi Bali 
I Made Nada, dkk. : Model Penanggulangan Sedimentasi Danau Berbasis Masyarakat .....

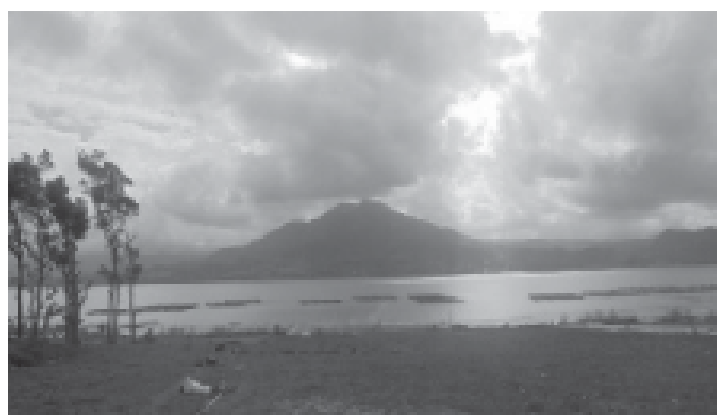

Danau Batur

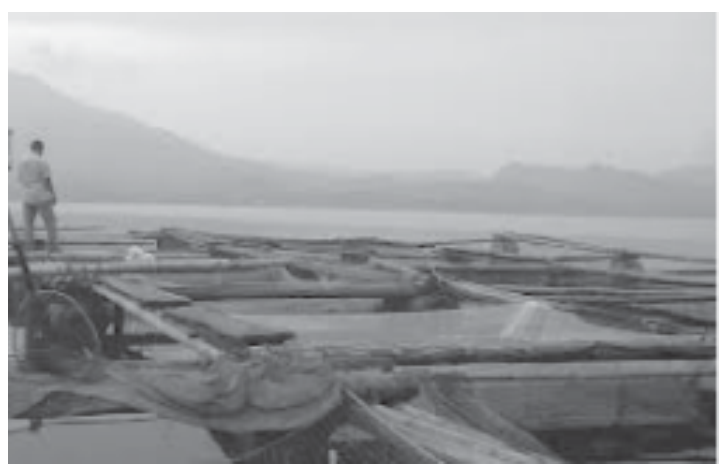

Keramba Ikan

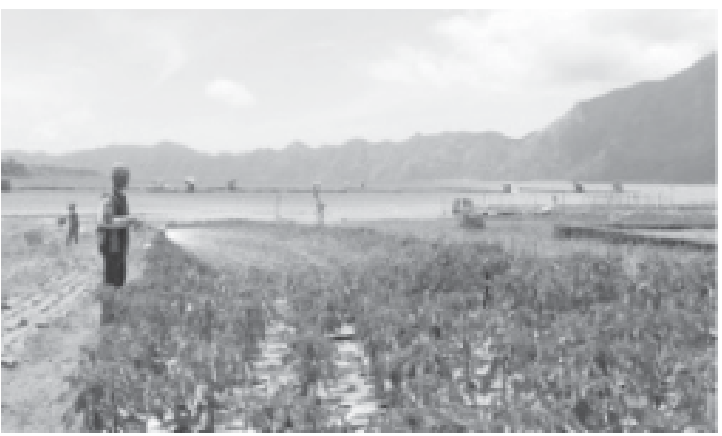

Pertanian di Kedisan

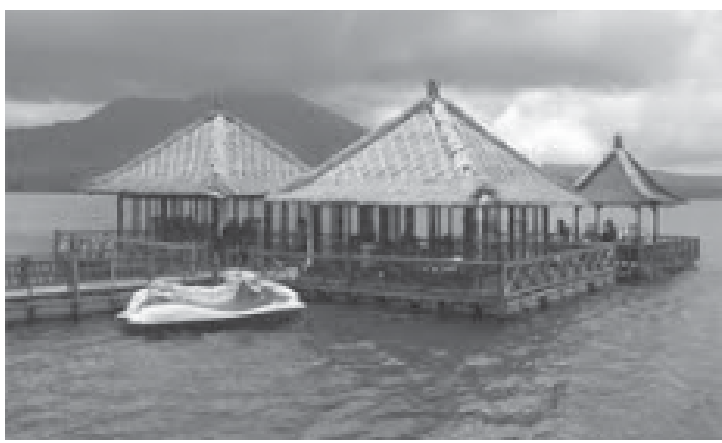

Restoran Apung

Gambar 4. Pemanfaatan Kawasan Danau Batur

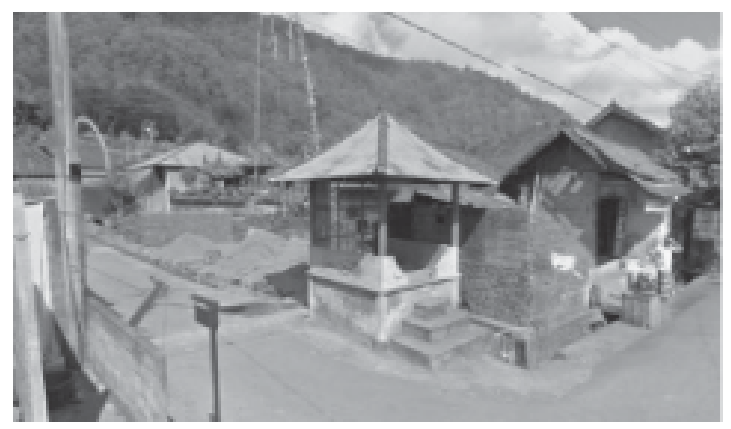

Kawasan Pemukiman

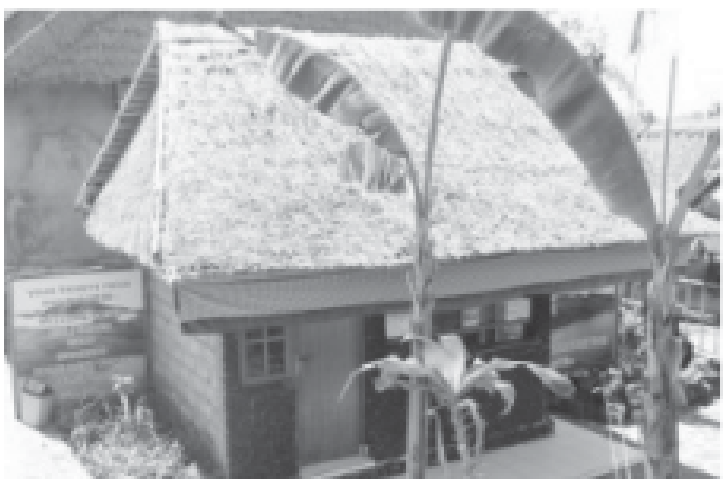

Penginapan di Toya Bungkah

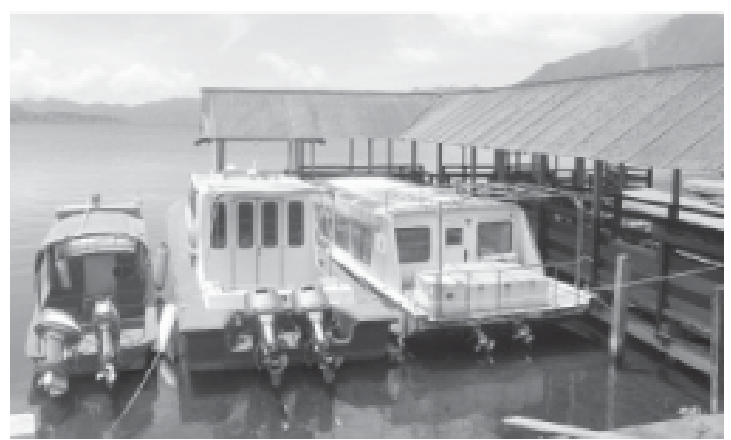

Dermaga

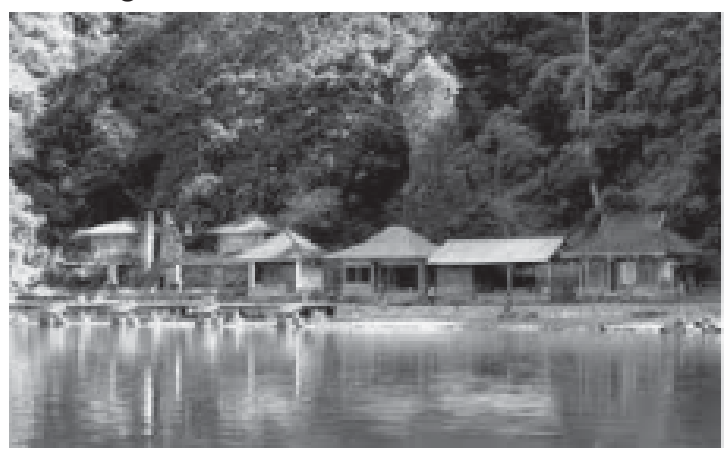

Pura Dalem Trunyan 


\subsection{Survey Pendaluan di Kawasan Danau Batur Kabupaten Bangli}

Dari hasil survey yang telah dilakukan menunjukan perkembangan penduduk serta kegiatan pariwisata yang semakin pesat di sekitar wilayah Danau Batur kerap menimbulkan permasalahan yang kompleks sehingga memerlukan pengelolaan yang intensif. Masalah yang terjadi akan berakibat pada penurunan kualitas air danau, potensi eutrofikasi (kesuburan airyang semakin meningkat), pendangkalan yang akan merubah ekosistem danau secara keseluruhan gambar 4.2

Batas dari sempa dan danau Batur belum jelas, ini dikarenakan banyaknya warga sekitar yang menggunakan sempa dan danau sebagai lahan untuk pertanian gambar 4.3.

Pada saat air danau surut,warga langsung menanami lahan yang tidak tergenang air danau dengan tanaman holtikultural. Sehingga saat air danau meluap, lahan tersebut terendam dan pupuk yang terkandung dalam tanah tersebut akan ikut tercampur dengan air danau sehingga kualits air danau akan turun selain sebagai sumber air baku untuk air minum, air dari Danau Batur juga diperuntukkan aktivitas perkebunan sayur yang ada di sekitar danau. Berbagai komoditas sayur yang ditanam meliputi bawang merah, kol, tomat dan cabai. Petani sayur sekitar danau batur menyedot air secara langsung dari danau. Wilayah barat Danau Batur yang termasuk lahan kritis tidak menyurutkan semangat petani untuk melakukan aktivitas perkebunan sayur khususnya bawang merah. Dengan menggunakan pipa atau selang air yang panjangnya hingga beberapa kilometer mereka menyedot air danau batur untuk menyirami kebun mereka yang berada di kaki Gunung Batur. Hal ini secara tidak langsung mengakibatkan volume air danau dapat berkurang secara signifikan. Danau Batur merupakan salah satu wilayah perairan yang dimanfaatkan masyarakat selain oleh nelayan perikanan tangkap juga sebagai pusat kegiatan budidaya perikanan. Alat tangkap yang dominan digunakan di Danau Batur yaitu jaring insang (gillnet). Pada tahun 2011 sesuai dengan kebijakan yang dikeluarkan dari menteri Kelautan dan Perikanan yang menetapkan danau Batur sebagai area minapolitan membuat para nelayan perikanan tangkap beralih menjadi pembudidaya (Anonimous1, 2011). Sistem budi daya yang digunakan adalah Karamba Jaring Apung. Banyaknya keramba ikan di danau Batur membuat masyarakat sekitar memberikan pakan ikan yang sangat berlebihan sehingga membuat kualitas air di danau batur menjadi tercemar karena pakan ikan tersebut. Kegiatan pertambangan yang terdapat di kawasan sekitar Danau Batur adalah pertambangan bahan galian golongan $\mathrm{C}$ jenis pasir. Lokasi penambangan pasir terdapat di Desa Songan A. Di satu sisi kegiatan ini akan dapat menambah penghasilan masyarakat tetapi dari segi lingkungan sangat merusak bentang alam, apalagi sistem pertambangan yang tidak direncanakan/diatur dengan baik, sehingga mudah menimbulkan longsor atau memunculkan areal-areal genangan baru. Tingkat erosinya tergolong ringan sampai berat. Dengan demikian untuk lokasi-lokasi yang tergolong mengalami erosi berat akan mempercepat terjadinya pendangkalan danau yang pada akhirnya mengurangi kapasitas danau untuk menampung air. Lokasi sekitar pantai Songan A dan B kemudian sekitar Desa Kedisan hingga Desa Buahan pada umumnya mempunyai zona litoral yang lebar dengan tipe dasar perairan yang dominan berupa pasir berlumpur. Lokasi-lokasi ini mengalami tingkat sedimentasi yang relatif tinggi. Faktor penggunaan dan pengelolaan lahan di sekitar danau berpengaruh besar pada tingkat sedimentasi di Danau. Penggunaan lahan untuk pertanian hortikultura dengan pemakaian pupuk organik yang tinggi volume dan intensitasnya menyebabkan laju sedimentasi sangat tinggi yang dibawa oleh aliran permukaan (surfacerunoff) pada saat musim hujan gambar 3.5.

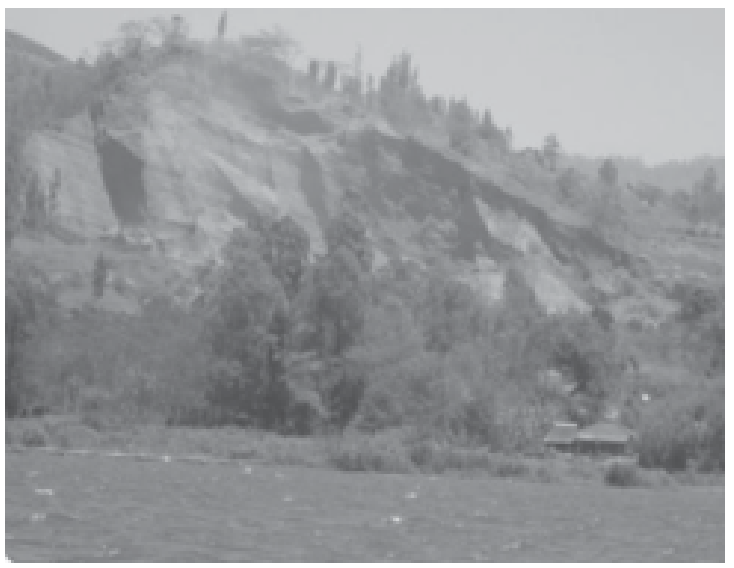

Gambar 5. Galian C di Utara Danau Batur 
I Made Nada, dkk. : Model Penanggulangan Sedimentasi Danau Berbasis Masyarakat .....

Tabel 3.1 Kondisi Eksisting Danau Batur

\begin{tabular}{|c|l|l|}
\hline No & \multicolumn{1}{|c|}{ Ur a I a n } & \multicolumn{1}{c|}{ Keterangan } \\
\hline 1 & Lokasi & Kecamatan Kintamani, Kabiupaten Bangli \\
\hline 2 & Letak Geografis & $\begin{array}{l}115^{\circ} 22^{\prime} 42^{\prime \prime}-115^{\circ} 25^{\prime} 33 \mathrm{BT} \\
8^{\circ} 17^{\prime} 14^{\prime \prime}-8^{\circ} 13^{\prime} 19 \mathrm{LS}\end{array}$ \\
\hline 3 & Curah Hujan Tahunan & $1.809 \mathrm{~mm}$ \\
\hline 4 & Evaluasi Muka Air Danau & $1.032 \mathrm{~m} \mathrm{dpl}$ \\
\hline 5 & Type Danau & Danau Kaldera \\
\hline 6 & Type Perairan & Danau Alam \\
\hline 7 & Kedalaman (maks.) & $80 \mathrm{~m}$ \\
\hline 8 & Luas Permukaan Danau & $16.213 \mathrm{Km}^{2}$ \\
\hline 9 & Volume Danau & $773,33 \mathrm{~m}^{3}$ \\
\hline 10 & Inlet (inflow) & Hanya dari DTA \\
\hline 11 & Outlet (outflow) & Tidak ada \\
\hline
\end{tabular}

Sumber : Balai Wilayah Sungai Bali-Penida

Tabel 3.2. Penggunaan Lahan di Kawasan Danau Batur

\begin{tabular}{|c|l|c|c|c|}
\hline No & \multicolumn{1}{|c|}{ Uraian } & 1999 & 2009 & 2015 \\
\hline 1 & Ladang & 1634,07 & 536,67 & 636,67 \\
\hline 2 & Hutan alam dengan kerapatan tinggi & 608,65 & 228,56 & 228,56 \\
\hline 3 & Hutan alam dengan kerapatan sedang & 260,85 & 533,32 & 433,32 \\
\hline 4 & Permukiman & 1435,20 & 2217,00 & 2342,00 \\
\hline 5 & Perkebunan & 144,89 & 529,22 & 529,22 \\
\hline 6 & Semak belukar & 312,34 & 383,23 & 258,23 \\
\hline 7 & Giopark & 1066,00 & 1034,00 & 1034,00 \\
\hline
\end{tabular}

Satuan dalam Ha

Sumber : Balai Wilayah Sungai Bali-Penida

Tabel 3.3 Sedimentasi Danau Batur

\begin{tabular}{|c|l|c|c|}
\hline No & \multicolumn{1}{|c|}{ Morfometri Danau } & Tahun 2013 & Tahun 2015 \\
\hline 1 & Luas air $\left(\mathrm{km}^{2}\right)$ & 14,71 & 16,55 \\
\hline 2 & Luas air $(\mathrm{ha})$ & 1471 & 1655 \\
\hline 3 & Volume air $\left(\right.$ juta $\left.\mathrm{m}^{3}\right)$ & 820,54 & 773,33 \\
\hline 4 & Kedalaman air maksimum $(\mathrm{m})$ & 88 & 80 \\
\hline 5 & Sedimentasi $\left(\mathrm{m}^{3}\right)$ & & $5.980,47$ \\
\hline 6 & Periode (tahun) & & 3 \\
\hline 7 & Tingkat sedimentasi $\left(\mathrm{m}^{3} /\right.$ tahun) & & $1.993,49$ \\
\hline
\end{tabular}

Sumber :Balai Wilayah Sungai Bali-Penida 
Tabel 3.4 Hasil Pengukuran Luas Danau

\begin{tabular}{|l|l|c|c|c|}
\hline \multirow{2}{*}{ No } & \multicolumn{2}{|c|}{ Ur a i a n } & \multicolumn{3}{|c|}{ Luas (Ha) } \\
\cline { 3 - 5 } & & 1999 & 2009 & 2015 \\
\hline 1 & Danau Batur & 1661 & 1630,4 & 1621,3 \\
\hline 2 & Danau Beratan & 394,41 & 386 & 376,4 \\
\hline 3 & Danau Buyan & 439 & 413,15 & 476,6 \\
\hline 4 & Dnau Tamblingan & 146,6 & 143,50 & 146,1 \\
\hline
\end{tabular}

Sumber :Balai Wilayah Sungai Bali-Penida

\subsection{Survey Pendaluan di Kawasan Danau Beratan di Kabupaten Tabanan}

Danau Beratan adalah sebuah danau yang terletak di kawasan Bedugul, Desa Candikuning, Kecamatan Baturiti, Kabupaten Tabanan, Bali. Danau Beratan merupakan danau kaldera dengan ketinggian $1231 \mathrm{~m}$ diatas permukaan laut, dengan luas $3,8 \mathrm{~km}$ serta kedalaman maksima $122 \mathrm{~m}$. Volume air danau ini $0,049 \mathrm{~km}^{3}$ dan merupakan danau tertutup

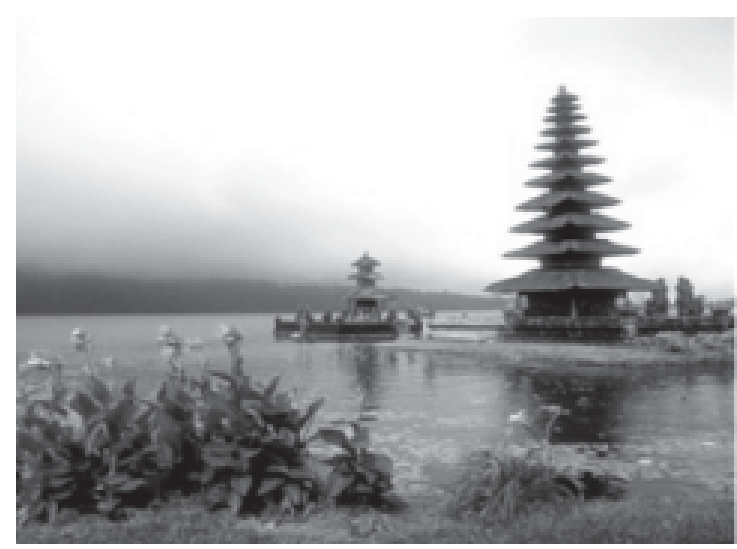

Gambar 6 Danau Beratan

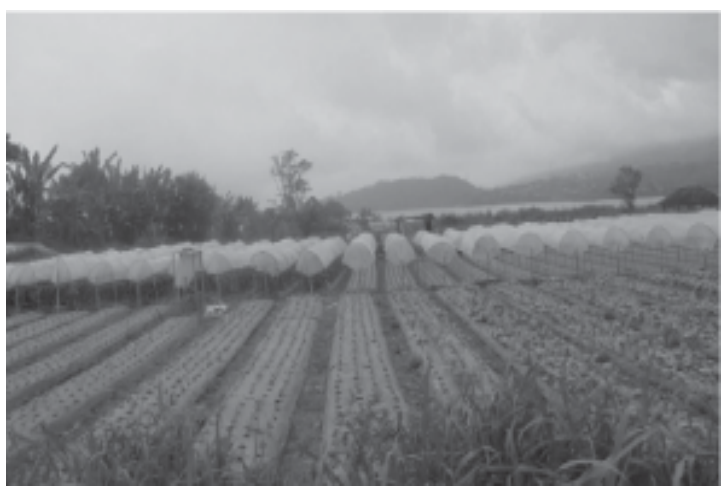

Gambar 7. Lahan pertanian
Dari hasil survey yang dilakukan, bahwa batas dari sempadan danau Beratan cukup jelas, tetapi di bagian utara danau Beratan masih belum jelas ini dikarenakan banyaknya warga sekitar yang menggunakan sempadan danau sebagai lahan untuk pertanian. Pada saat air danau surut, warga langsung menanami lahan yang tidak tergenang air danau dengan tanaman holtikultural. Sehingga saat air danau meluap, lahan tersebut terendam dan pupuk yang terkandung dalam tanah tersebut akan ikut tercampur dengan air danau sehingga kualitas air danau akan turun.

Danau Beratan kini menjadi daya tarik bagi para wisatawan. Di danau ini banyak disediakan permainan air seperti boat, perahu dan sebagainya gambar 4.8. Ini juga berdampak pada kualitas air danau, boat-boat yang dipakai dalam permainan air di danau beratan menghasilkan limbah yang langsung terbuang ke danau. Tidak itu juga banyaknya masyarakat yang menggunakan sempadan danau sebagai lahan untuk pertanian. Pengairan tanaman dan kegiatan lainnya mempergunakan pompa yang pengambilan airnya di Danau Beratan.

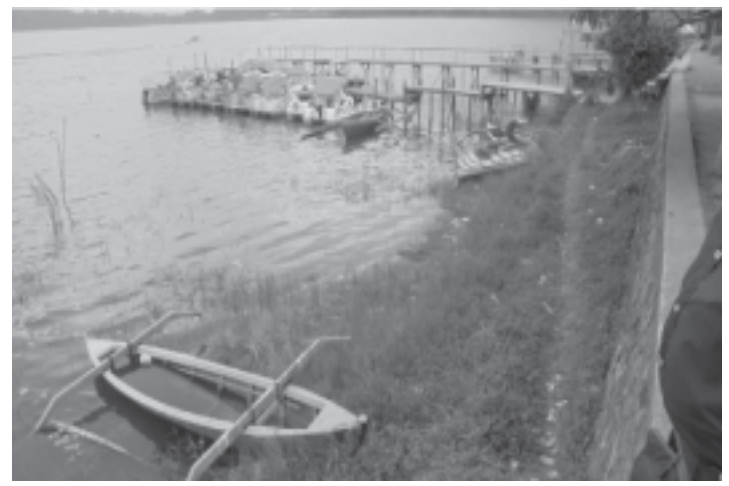

Gambar 8. Permainan Air 


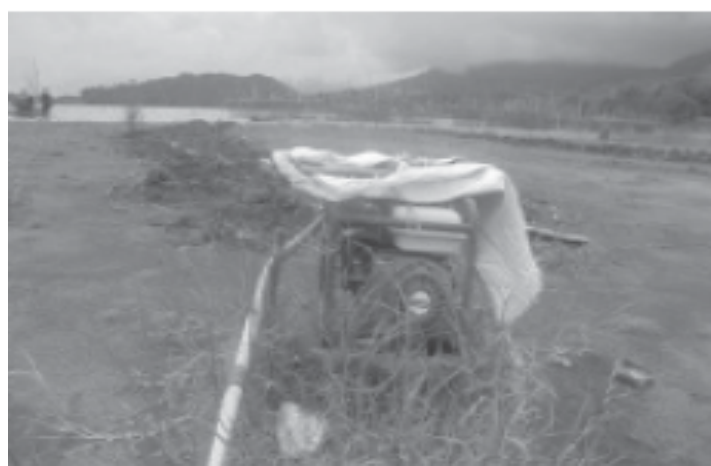

Pompa Desa Candi Kuning

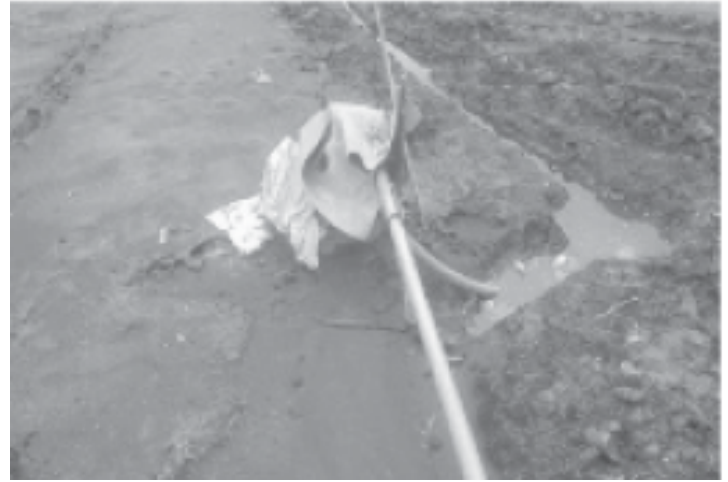

Pompa Ds. Batunya

Gambar 9. Letak Pompa Pengambilan Air di Danau Beratan

Tabel 3.5 Kondisi Eksisting Danau Beratan

\begin{tabular}{|c|l|l|}
\hline No & \multicolumn{1}{|c|}{ Ura I a } & \multicolumn{1}{c|}{ Keterangan } \\
\hline 1 & Lokasi & Kec. Baturiti, Kab. Tabanan \\
\hline 2 & Letak Geografis & $\begin{array}{l}115^{\circ} 9^{\prime} 53^{\prime \prime}-115^{\circ} 11^{\prime} 09^{\prime \prime} \mathrm{BT} \\
8^{\circ} 15^{\prime} 44^{\prime \prime}-8^{\circ} 17^{\prime} 01^{\prime \prime} \mathrm{LS}\end{array}$ \\
\hline 3 & Curah Hujan Tahunan & $2.439,54 \mathrm{~mm}$ \\
\hline 4 & Evaluasi Muka Air Danau & $1.230 \mathrm{~m} \mathrm{dpl}$ \\
\hline 5 & Type Danau & Danau Sesar-Lingkar Kaldera \\
\hline 6 & Type Perairan & Danau Alam \\
\hline 7 & Kedalaman (maks.) & $20 \mathrm{~m}$ \\
\hline 8 & Luas Permukaan Danau & $3,764 \mathrm{~km} 2$ \\
\hline 9 & Volume Danau & 29,74 juta m3 \\
\hline 10 & Inlet (inflow) & Hanya dari DTA \\
\hline 11 & Outlet (outflow) & Ada (berupa bangunan spillway) \\
\hline
\end{tabular}

Sumber : Balai Wilayah Sungai Bali - Penida

Tabel 3.6 Penggunaan Lahan di Kawasan Danau Beratan

\begin{tabular}{|c|l|c|c|c|}
\hline No & \multicolumn{1}{|c|}{ Uraian } & 1999 & 20011 & 2015 \\
\hline 1 & Ladang & 114,46 & 117,83 & 270,64 \\
\hline 2 & Hutan alam dengan kerapatan tinggi & 931,56 & 808,68 & 1387,51 \\
\hline 3 & Hutan alam dengan kerapatan sedang & 372,23 & 217,95 & 229,04 \\
\hline 4 & Permukiman & 424,79 & 565,89 & 598,73 \\
\hline 5 & Perkebunan & 533,66 & 713,23 & 112,76 \\
\hline 6 & Semak belukar & 8,24 & 4,37 & 3,26 \\
\hline
\end{tabular}

Satuan dalam Ha

Sumber : Balai Wilayah Sungai Bali-Penida 
Tabel 3.7 Sedimentasi Danau Beratan

\begin{tabular}{|c|l|c|c|}
\hline No & \multicolumn{1}{|c|}{ Morfometri Danau } & Tahun 2013 & Tahun 2015 \\
\hline 1 & Luas air $\left(\mathrm{km}^{2}\right)$ & 4,29 & 3,89 \\
\hline 2 & Luas air (ha) & 429,14 & 389,08 \\
\hline 3 & Volume air (juta $\left.\mathrm{m}^{3}\right)$ & 63,3 & 29,74 \\
\hline 4 & Kedalaman air maksimum $(\mathrm{m})$ & 23 & 20 \\
\hline 5 & Sedimentasi $\left(\mathrm{m}^{3}\right)$ & & $2.443,32$ \\
\hline 6 & Periode (tahun) & & 3 \\
\hline 7 & Tingkat sedimentasi $\left(\mathrm{m}^{3} /\right.$ tahun $)$ & & 814,44 \\
\hline
\end{tabular}

Sumber :Balai Wilayah Sungai Bali-Penida

\subsection{Survey Pendaluan di Kawasan Danau Buyan Kabupaten Buleleng}

Danau Buyan adalah sebuah danau yang terletak di kawasan Desa Pancasari, Kecamatan Sukasada, Kabupaten Buleleng, Bali. Danau ini merupakan satu dari tiga danau kembar yang terbentuk di dalam sebuah kaldera besar. Ia diapit oleh dua danau lainnya, yaitu Danau Tamblingan di sebelah barat dan Danau Beratan di timur. Danau Buyan adalah yang terbesar dari ketiganya.

Didanau Buyan sudah terdapat batas sempadan. Batas Sempadan dibangun dengan pasangan batu sehingga air danau tidak bisa meluap. Tetapi dari survey di lapangan, tanggul itu tidak sanggup menahan air bila danau meluap. Luapan danau tersebutmenggenangi lahan pertanian wargadisekitar.

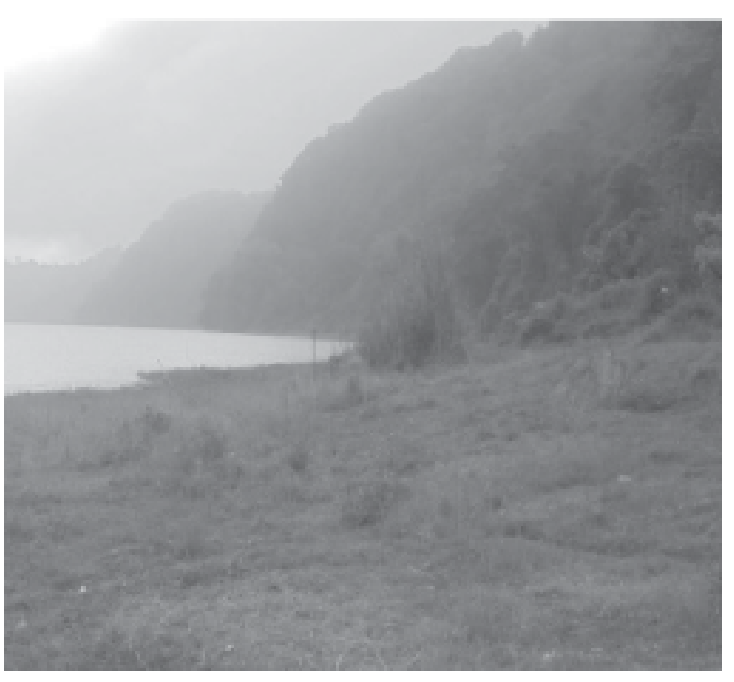

Gambar 10. Danau Buyan

Tabel 3.8 Kondisi Eksisting Danau Buyan

\begin{tabular}{|c|l|l|}
\hline No & \multicolumn{1}{|c|}{ Ura I a } & \multicolumn{1}{c|}{ Keterangan } \\
\hline 1 & Lokasi & Kec. Sukasada, Kab. Buleleng \\
\hline 2 & Letak Geografis & $\begin{array}{l}115^{\circ} 5^{\prime} 28^{\prime \prime}-11506^{\prime} 10^{\prime \prime} \mathrm{BT} \\
8^{\circ} 14^{\prime} 55^{\prime \prime}-8015^{\prime} 52^{\prime \prime} \mathrm{LS}\end{array}$ \\
\hline 3 & Curah Hujan Tahunan & $2.294 \mathrm{~mm}$ \\
\hline 4 & Evaluasi Muka Air Danau & $1.275 \mathrm{~m} \mathrm{dpl}$ \\
\hline 5 & Type Danau & Kaldera \\
\hline 6 & Type Perairan & Danau Alam \\
\hline 7 & Kedalaman (maks.) & $31,7 \mathrm{~m}$ \\
\hline 8 & Luas Permukaan Danau & $4,81 \mathrm{~km}$ \\
\hline 9 & Volume Danau & 116,25 juta m3 \\
\hline 10 & Inlet (inflow) & Hanya dari DTA \\
\hline 11 & Outlet (outflow) & Tidak ada \\
\hline
\end{tabular}

Sumber : Balai Wilayah Sungai Bali - Penida 
I Made Nada, dkk. : Model Penanggulangan Sedimentasi Danau Berbasis Masyarakat .....

Tabel 3.9 Penggunaan Lahan di Kawasan Danau Buyan

\begin{tabular}{|c|l|c|c|c|}
\hline No & \multicolumn{1}{|c|}{ Uraian } & 1999 & 20011 & 2015 \\
\hline 1 & Ladang & 736,51 & 547,81 & 600,97 \\
\hline 2 & Hutan alam dengan kerapatan tinggi & 744,57 & 632,27 & 286,67 \\
\hline 3 & Hutan alam dengan kerapatan sedang & 323,43 & 687,79 & 593,59 \\
\hline 4 & Permukiman & 141,05 & 407,16 & 485,23 \\
\hline 5 & Perkebunan & 75,47 & 87,53 & 62,17 \\
\hline 6 & Semak belukar & 16,03 & 11,94 & 8,37 \\
\hline
\end{tabular}

Satuan dalam Ha

Sumber : Balai Wilayah Sungai Bali-Penida

Tabel 3.10 Sedimentasi Danau Buyan

\begin{tabular}{|c|l|c|c|}
\hline No & \multicolumn{1}{|c|}{ Morfometri Danau } & Tahun 2013 & Tahun 2015 \\
\hline 1 & Luas air $\left(\mathrm{km}^{2}\right)$ & 4,8 & 4,6 \\
\hline 2 & Luas air (ha) & 480 & 460 \\
\hline 3 & Volume air (juta $\left.\mathrm{m}^{3}\right)$ & 116,25 & 49,6 \\
\hline 4 & Kedalaman air maksimum (m) & 80 & 60 \\
\hline 5 & Sedimentasi $\left(\mathrm{m}^{3}\right)$ & 2216.799 & \\
\hline 6 & Periode (tahun) & 3 & \\
\hline 7 & Tingkat sedimentasi $\left(\mathrm{m}^{3}\right.$ /tahun) & 738,933 & \\
\hline
\end{tabular}

Sumber : Balai Wilayah Sungai Bali-Penida

Selain adanya evaporasi, faktor pengurangan air danau dipengaruhi oleh besar kecilnya penggunaan air. Dari hasil pengamatan dan survei penggunaan air, pemanfaatan air Danau Buyan terdiri dari:

1) Pemompaan oleh PDAM.

2) Pemompaan oleh DesaWanagiri.

3) Pemompaan untuk digunakan penyiraman lahan pertanian dengan membuat sumursumur gali.

Pengambilan air secara langsung dilakukan oleh penduduk Desa Wanagiri dipergunakan untuk kebutuhan air bersih bagi penduduk dan restoran, dengan membuat sumur-sumur pemompaan yang menggunakan pompa dengan debit.2 liter/dt yang dilakukan selama 10 jam setiap harinya dengan jumlah total $72 \mathrm{~m}^{3} / \mathrm{dt}$ untuk memenuhi kebutuhan 59 kk (kelompok pengelola air Desa Wanagiri) dan restoran yang ada di sekitarnya.

\subsection{Survey Pendaluan di Kawasan Danau Tamblingan Kabupaten Buleleng}

Danau Tamblingan adalah sebuah danau yang terletak di lereng sebelah utara Gunung Lesung, kawasan Desa Munduk, Kecamatan Banjar, Kabupaten Buleleng, Bali. Danau ini merupakan satu dari tiga danau kembar yang terbentuk di dalam sebuah kaldera besar. Di sebelah timur berturutturut terdapat Danau Buyan dan Danau Beratan. Diapit oleh hutan disekelilingnya serta terletak didaerah dataran tinggi membuat lingkungan danau ini berhawa sejuk 4.13. Sebagai salah satu objek wisata alam, Danau Tamblingan tidak dikembangkan ke arah pariwisata modern demi menjaga kelestarian alam dan lingkungannya. Hal yang menjadi daya tarik utama tempat ini, bukan hanya pesona alamnya, namun juga karena banyaknya pura yang menyimpan sejarah dan perkembangan peradaban serta kebudayaan Bali, khususnya menyangkut pembentukan dan perkembangan DesaTamblingan. 


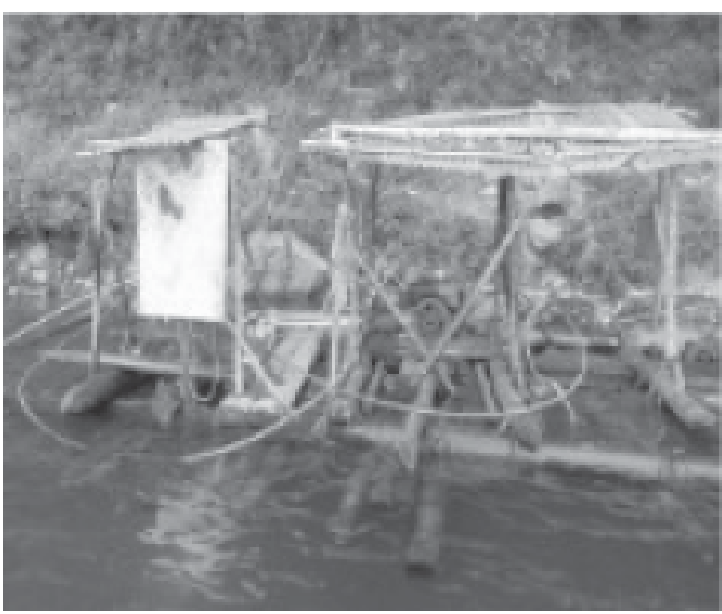

Gambar 11. Danau Tamblingan
Dari hasil survey yang dilakukan, bahwa batas dari sempadan dari danau Tamblingan belum jelas, ini disebabkan kawasan danau Tamblingan masih dikelilingi kawasan hutan, sehingga dalam perencanaan batas sempadan harus direncanakan dengan baik sehingga batas sempadan yang direncanakan tidak merusak kawasan sekitarnya. Danau Tamblingan dimanfaatkan warga sebagai tempat olah raga memancing. Karena tidak ada perahu yang menggunakan mesin, tetapi ada warga yang menggunakan air dari danu tamblingan untuk mengairi lahan pertanian yang ada di desa wanagiri. Mereka menggunakan mesin pompa yang menggunakan bahan bakar solar. Dari mesin itu, dengan tidak sengaja mesin itu menghasilkan limbah minyak yang langsung tumpah ke air danau.

Tabel 3.11 Kondisi Eksisting Danau Tamblingan

\begin{tabular}{|c|l|l|}
\hline No & \multicolumn{1}{|c|}{ Ur a I a n } & \multicolumn{1}{c|}{ Keterangan } \\
\hline 1 & Lokasi & Kec. Banjar, Kerb. Buleleng \\
\hline 2 & Letak Geografis & $\begin{array}{l}115^{\circ} 5^{\prime} 28^{\prime \prime}-115^{\circ} 6^{\prime} 10^{\prime \prime} \mathrm{BT} \\
8^{\circ} 14^{\prime} 55^{\prime \prime}-8^{\circ} 15^{\prime} 52^{\prime \prime} \mathrm{LS}\end{array}$ \\
\hline 3 & Curah Hujan Tahunan & $2.467,05 \mathrm{~mm}$ \\
\hline 4 & Evaluasi Muka Air Danau & $1.216 \mathrm{~m} \mathrm{dpl}$ \\
\hline 5 & Type Danau & Danau Sesar-Lingkar Kaldera \\
\hline 6 & Type Perairan & Danau Alam \\
\hline 7 & Kedalaman (maks.) & 37 m \\
\hline 8 & Luas Permukaan Danau & $1,461 \mathrm{~km} 2$ \\
\hline 9 & Volume Danau & 19,8 juta m3 \\
\hline 10 & Inlet (inflow) & Hanya dari DTA \\
\hline 11 & Outlet (outflow) & Tidak ada \\
\hline
\end{tabular}

Sumber : Balai Wilayah Sungai Bali - Penida

Tabel 3.12 Penggunaan Lahan di Kawasan Danau

\begin{tabular}{|c|l|c|c|c|}
\hline No & \multicolumn{1}{|c|}{ Uraian } & 1999 & 20011 & 2015 \\
\hline 1 & Ladang & 160,06 & 176,93 & 151,68 \\
\hline 2 & Hutan alam dengan kerapatan tinggi & 406,00 & 442,59 & 465,76 \\
\hline 3 & Hutan alam dengan kerapatan sedang & 265,00 & 189,68 & 119,19 \\
\hline 4 & Permukiman & 18,92 & 38,05 & 40,73 \\
\hline 5 & Perkebunan & 24,84 & 87,53 & 80,92 \\
\hline 6 & Semak belukar & 6,78 & 11,94 & 7,388 \\
\hline
\end{tabular}

Satuan dalam $\mathrm{Ha}$

Sumber : Balai Wilayah Sungai Bali-Penida 
I Made Nada, dkk. : Model Penanggulangan Sedimentasi Danau Berbasis Masyarakat .....

Tabel 3.13 Sedimentasi Danau Tamblingan

\begin{tabular}{|c|l|c|c|}
\hline No & \multicolumn{1}{|c|}{ Morfometri Danau } & Tahun 2013 & Tahun 2015 \\
\hline 1 & Luas air $\left(\mathrm{km}^{2}\right)$ & 1,57 & 1,37 \\
\hline 2 & Luas air (ha) & 1570 & 1370 \\
\hline 3 & Volume air (juta $\left.\mathrm{m}^{3}\right)$ & 30,4 & 19,8 \\
\hline 4 & Kedalaman air maksimum (m) & 40 & 37 \\
\hline 5 & Sedimentasi $\left.\mathrm{m}^{3}\right)$ & & $1.574,63$ \\
\hline 6 & Periode (tahun) & & 3 \\
\hline 7 & Tingkat sedimentasi $\left(\mathrm{m}^{3} /\right.$ tahun $)$ & & 524,87 \\
\hline
\end{tabular}

Sumber :Balai Wilayah Sungai Bali-Penida

\section{REFERENSI}

Abdurachman, Abujamin dan U. Kurnia. 1984. Soil and crop management soil conservation effort. Journal of Soil and Fertilizer. No. 3, 1984: Soil Research Institute, Bogor.

Adnyana, I W. S. 2001. Prediksi Erosi dan Perencanaan Konservasi Tanah dan Air di Kawasan Danau Beratan, Buyan dan Tamblingan. AGRITROP. Jurnal Ilmu-ilmu Pertanian. 20(1). Hal.: 36-41.

Arsyad, S. 1989. Konservasi Tanah dan Air. Bogor: Penerbit IPB Press.

Asdak, C., 2002. Hidrologi dan Pengelolaan Daerah Aliran

Badan Pengendalian Dampak Lingkungan, 1996. Kep-56 Tahun 1996 tentang Pedoman Mengenai Ukuran Dampak Penting. Kepala Badan Pengendalian Dampak Lingkungan. Bali.

Gubernur Bali, 2000. Keputusan Gubernur Bali Nomor 515 Tahun 2000 Tentang Standar Baku Mutu lingkungan.Gubernur Bali. Denpasar.

Jeffries, M. and Mills, D. 1996. Freshwater Ecology, Principles, and Application. Johnn Wiley and Sons, Chichester, UK. 285 p.

Kementrian Lingkungan Hidup, 2001. PPRI No. 82 Tahun 2001 Tentang Pengelolaan Kualitas Air dan Pengendalian Pencemaran Air. Kementrian Lingkungan Hidup. Jakarta.

Kirkby M.J., Bissonais Y. Le., Coulthard T.J., Daroussin J., and McMahon M.D., 2000. The Development Of Land Quality Indicators For
Soil Degradation By Water Erosion. (http:// www.elserver.com/locate/agree).

Kurnia, U., T. Budhyastoro dan N. Suharta. 1987. Penelitian Metode Pemetaan erosi Potensial dan Aktual di Kabupaten solok, Sumatera barat. Prosiding Pertemuan Teknis Penelitian Tanah, Cipayung, 18 - 20 Maret 1985. Pusat Penelitian Tanah, Bogor.

LIPI, 2005. Survei Lapangan Dalam Rangka Pengumpulan Data Analisis Daya Dukung dan Daya Tampung Lingkungan Hidup di Kawasan Bedugul. UPT BKT Kebun Raya 'Eka Karya’ Bali - LIPI. Bedugul.

Miller, G.T. 1979. Living in the Environment, 2. Wadsworth, Belmont, Cal.

Machbub, baddrudin. 2010. Model Perhitungan Daya Tampung Beban Pencemaran Air Danau dan Waduk. http://limnologi.lipi.go.id/katalog/ index.php/searchkatalog/downloadDatabyId/ $252 / 3_{\text {_COdel_perhitungan_daya }}$ tampung_Badruddin.pdf, diunduh 1 Juni 2016

Natsir, dkk. 2013. Karakteristik Batimetri Danau Empangau-Kalimantan Barat. http://p3sdlp. litbang.kkp.go.id/segara/index.php/Jurnal Segara/article/view/31, diunduh 27 Mei 2016

Odum, E.P. 1971. Fundamental of Ecology. W.B. Sanders Company, Philadelphia.

Sastrawijaya, 1991. Pencemaran Lingkungan. PT. Rineka Cipta, Jakarta.

Sembiring, dkk. 2014. Analisis Sedimentasi di Muara Sungai Panasen. http://ejournal.unsrat.ac.id/ index.php/jss/article/view/4763, diunduh 1 Juni 2016 
Sittadewi, Euthalia Hanggari. 2008. Fungsi Strategis Danau Tondano, Perubahan Ekosistem, dan Masalah yang Terjadi. http://ejurnal.bppt.go.id/ index.php/JTL/article/view/533, diunduh $25 \mathrm{Mei}$ 2016

Suratmo, G.F. 2004. Analisis Mengenai Dampak Lingkungan. Yogyakarta : Gadjah Mada University Press.
Sutamihardja, R.T.M. 1978. Kualitas dan Pencemaran Lingkungan. Bogor: Pascasarjana Jurusan Pengelolaan Sumberdaya Alam dan Lingkungan, IPB, Bogor.

Wardhana, W.a. 2001. Dampak Pencemaran Lingkungan. Penerbit Andi, Yogyakarta. 